\title{
The effect of varying crude protein level and the proportions of fibre in diets containing a mixture of meat-and-bone meal and wheat bran
}

\section{as the only protein source on nitrogen balance indices and energy} digestibility in the rat

\author{
By B. O. EGGUM ${ }^{1}$, R. M. BEAMES ${ }^{2}$ AND K. E. BACH KNUDSEN ${ }^{1}$ \\ ${ }^{1}$ National Institute of Animal Science, Department of Animal Physiology \& Chemistry, \\ Rolighedsvej 25, DK-1958, Copenhagen V, Denmark \\ ${ }^{2}$ Department of Animal Science, University of British Columbia, Vancouver, \\ BC V6T 2A2, Canada
}

(Received 27 November 1985 - Accepted 21 April 1986)

1. The experiment was designed to investigate the effect of protein level in diets on apparent protein digestibility (AD), true protein digestibility (TD), biological value (BV), net protein utilization (NPU) and energy digestibility (DE) in rats. The design involved fourteen dietary treatments in which a combination of wheat bran and meat-and-bone meal ( $1: 1, \mathrm{w} / \mathrm{w}$ dry matter $(\mathrm{DM})$ basis) was the only nitrogen source. Crude protein $(\mathrm{N} \times 6.25$; $\mathrm{CP}$ ) level ranged from 60 to $329 \mathrm{~g} / \mathrm{kg} \mathrm{DM}$ in approximately even increments. All diets contained a constant level of minerals and vitamins. The balance of the diet consisted of a $\mathrm{N}$-free mixture.

2. AD increased from 0.602 at $60 \mathrm{~g} \mathrm{CP} / \mathrm{kg} \mathrm{DM}$ to 0.702 at $120 \mathrm{~g} \mathrm{CP} / \mathrm{kg} \mathrm{DM}$, with little change at the higher levels of dietary protein. The fitting of a curve indicated an asymptote of $0 \cdot 721$.

3. TD did not vary significantly between 60 and $225 \mathrm{~g} \mathrm{CP} / \mathrm{kg} \mathrm{DM}$ (mean 0.781 ). At the higher protein levels there was a slight but significant reduction in the mean value $(0.758)$.

4. BV increased from 0.475 at $60 \mathrm{~g} \mathrm{CP} / \mathrm{kg} \mathrm{DM}$ to 0.498 at $80 \mathrm{~g} \mathrm{CP} / \mathrm{kg}$ DM where it plateaued, and then from $160 \mathrm{~g} \mathrm{CP} / \mathrm{kg} \mathrm{DM}$ it decreased at an increasing rate to 0.216 at $329 \mathrm{~g} \mathrm{CP} / \mathrm{kg} \mathrm{DM}$.

5. The response in NPU closely reflected that obtained with BV, rising from 0.370 to 0.384 , then declining to 0.162 at the highest $\mathrm{CP}$ concentration.

6. DE decreased linearly from 0.851 at $60 \mathrm{~g} \mathrm{CP} / \mathrm{kg} \mathrm{DM}$ to 0.617 at $329 \mathrm{~g} \mathrm{CP} / \mathrm{kg} \mathrm{DM}$.

7. The results confirmed that $A D$ values should only be compared at a defined protein level. TD was essentially independent of dietary CP level, except for a small reduction above $250 \mathrm{~g} \mathrm{CP} / \mathrm{kg}$, whereas BV and NPU were stable only within the range $80-140 \mathrm{~g} \mathrm{CP} / \mathrm{kg}$ DM. DE was negatively related to dietary CP and fibre level.

In order to study the effect of dietary protein level on protein utilization, Eggum (1973) carried out experiments with rats given increasing amounts of protein from casein supplemented with $10 \mathrm{~g}$ DL-methionine/ $\mathrm{kg}$ and soya-bean meal. The conclusion from these experiments was that true protein digestibility (TD) is independent of dietary protein level, whereas apparent protein digestibility (AD) and biological value (BV) are not. In a later study, Beames \& Eggum (1981) showed that the inclusion of raw potato starch, which partly resists digestion by $\alpha$-amylase (EC 3.2.1.1) in the small intestine (Fleming \& Vose, 1979 ), reduced TD markedly when the protein source was casein, but the corresponding $\mathrm{BV}$ values were increased and blood urea values were decreased significantly with this treatment. This strongly indicated a movement of urea from the blood to the intestinal contents. The influence of raw potato starch on TD was, however, significantly less when fibre from cellulose or barley hulls was included. It was concluded that this moderating effect was probably due to a reduced transit time. Beames \& Eggum (1981) further showed that the inclusion of raw potato starch, when brown beans (Phaseolus vulgaris) were the protein source, had much less effect on TD and BV than when casein was the protein source. A suggested explanation was that the low disappearance of the dry matter (DM) and the protein of brown beans in the small intestine left sufficient energy and protein for maximum 
microbial growth in the hind-gut. This experiment thus showed that through dietary manipulation it is possible to affect nitrogen excretion patterns in rats.

There is no doubt that the presence of a population of micro-organisms in the alimentary tract of simple-stomached animals and man can affect $\mathbf{N}$ and energy metabolism, and that this effect under certain conditions will be significant (Mason \& Just, 1976; Mason et al. 1980). As well as having a degradative activity, the microflora of the hind-gut assimilate nitrogenous materials into their cell components. However, it is known that in simplestomached animals faecal $\mathrm{N}$ is affected not only by the quantity of dietary $\mathrm{N}$, but also by the amount and type of fibre starch and sucrose in the diet (Mason, 1978; Rerat, 1978; Bach Knudsen \& Eggum, 1984; Bach Knudsen et al. 1984; Eggum et al. 1985).

Recently it was shown by Donangelo \& Eggum (1985) that TD decreased when total dietary fibre increased, with this effect being more pronounced with wheat bran than with fine barley husk. The difference in response was explained as resulting from the larger $\mathrm{N}$ contribution from the bran than from the fine barley husk. In both cases, the decrease in TD associated with an increase in fibre level was due to poor digestibility of the $\mathrm{N}$ in the fibre source rather than to a decreased $\mathrm{N}$ digestibility of the basal diet. The work of Donangelo \& Eggum (1985) also indicated that the relatively high lysine content in the protein of both wheat bran and barley husk has a low availability. In work with nine protein sources, Eggum et al. (1985) showed that the effect of level of protein intake on protein utilization was dependent on both protein quality and the fibre concentration of the diet. Protein sources with a high BV were more affected than proteins of lower BV. It was further concluded from this work that TD is not always independent of dietary protein concentration.

The aim of the present experiment was to measure the effect of levels of dietary fibre and $\mathrm{N}$ from wheat bran and meat-and-bone meal on protein and energy utilization in rats. Wheat bran was used to stimulate the hind-gut microbial activity, mainly as an energy source, while meat-and-bone meal, being of poor protein quality, was included to provide the hind-gut microflora with $\mathrm{N}$ resulting from undigested residues or increased blood urea levels, or both.

\section{EXPERIMENTAL}

\section{Diets}

The design involved fourteen dietary treatments in which wheat bran and meat-and-bone meal were mixed $(1: 1, \mathrm{w} / \mathrm{w}$ on a DM basis) to constitute the only protein source. Crude protein $(\mathrm{N} \times 6.25 ; \mathrm{CP})$ ranged from $60 \mathrm{~g} / \mathrm{kg}$ DM to $329 \mathrm{~g} / \mathrm{kg} \mathrm{DM}$, with the increases being in approximately even increments (Table 1). Each diet contained a constant level of minerals $(40 \mathrm{~g} / \mathrm{kg})$ and vitamins $(16 \mathrm{~g} / \mathrm{kg})$ of a formula which has been described by Eggum (1973). The balance of each diet consisted of a $\mathrm{N}$-free mixture containing the following amounts $(\mathrm{g} / \mathrm{kg}$ air-dry matter): sucrose $89 \cdot 2$, cellulose $52 \cdot 0$, peanut oil $52 \cdot 0$, autoclaved potato starch $806 \cdot 8$.

\section{Animals and feeding}

The experimental procedure has been described by Eggum (1973). Groups of five Wistar male rats weighing approximately $70 \mathrm{~g}$ were used, with a preliminary period of $4 \mathrm{~d}$ and a balance period of $5 \mathrm{~d}$.

AD, TD, BV, net protein utilization (NPU) and apparent digestibility of energy (DE) were measured. 







\section{Chemical analyses}

$\mathrm{DM}, \mathrm{N}$, ash and crude fibre were determined by standard methods (Association of Official Analytical Chemists, 1975), fat by diethyl ether extraction after acid-hydrolysis (Stoldt, 1957), soluble sugars (sugar and starch) by the method of MacRae \& Armstrong (1968) and tannin by the method of Eggum \& Christensen (1975). Amino acids were determined by the method of Mason et al. (1980) and dietary fibre by the method of Asp et al. (1983).

\section{Statistical analyses}

All results were subjected to analysis of variance as outlined in the University of British Columbia program BMD:10V (Bjerring et al. 1975). Differences between means were tested at $P<0.05$, using Student Newman-Keuls' multiple-range test included in this program.

The relation between the dependent variables TD, BV, NPU and DE and the independent variable (dietary $\mathrm{N}$ concentration) were examined with a linear equation $(Y=a+b X)$ and a quadratic equation $\left(Y=a+b_{1} X+b_{2} X^{2}\right)$ with $Y$ the dependent variable and $X$ the independent variable, by the use of the University of British Columbia program TRP (Le \& Tenisci, 1978). The relation between AD and dietary $\mathrm{N}$ concentration was tested with a modified Weibull equation

$$
Y=a\left(1-\exp \left[-b X^{c}\right]\right),
$$

where $a$ is the asymptote and $b$ and $c$ are scale and shape parameters respectively (Yang et al. 1978). In deriving each curve, all individual values were used.

\section{RESULTS}

\section{Chemical composition}

The wheat bran and meat-and-bone-meal mixture $(1: 1, w / w, D M$ basis $)$ was of the following composition (g/kg DM): ash 203.7, N 54.9, diethyl-ether extract after acidhydrolysis 93.9 , starch and sugars 168.5 , total dietary fibre 242.8 , insoluble dietary fibre $227 \cdot 3$, soluble dietary fibre $15 \cdot 5$, tannin $8 \cdot 5$. Gross energy concentration was $17 \cdot 8 \mathrm{MJ}$ (4263 $\mathrm{kcal}) / \mathrm{kg}$. Amino acid concentration $(\mathrm{g} / \mathrm{kg} \mathrm{CP}$ ) was: alanine $69 \cdot 5$, arginine $71 \cdot 5$, aspartic acid $71 \cdot 5$, cystine $11 \cdot 4$, glutamic acid $145 \cdot 3$, glycine $125 \cdot 3$, histidine $18 \cdot 3$, isoleucine $29 \cdot 4$, leucine $59 \cdot 8$, lysine $46 \cdot 8$, methionine $11 \cdot 3$, phenylalanine $33 \cdot 6$, proline $86 \cdot 5$, serine $44 \cdot 0$, threonine $31 \cdot 3$, tyrosine $23 \cdot 8$, valine $43 \cdot 5$.

\section{Balance measurements with rats}

Results for all the balance measurements (AD, TD, BV, NPU and DE) are presented in both tabular (Table 2) and graphic forms (Figs. 1-5). The former was considered to be necessary so that the significance of the differences resulting from the changing protein concentrations could be clearly shown, while the latter, by the derivation of equations to fit the data, allowed a mathematical interpretation of the shape of the response.

\section{$A D$}

$\mathrm{AD}$ increased from 0.602 at $60 \mathrm{~g} \mathrm{CP} / \mathrm{kg} \mathrm{DM}$ to 0.702 at $120 \mathrm{~g} \mathrm{CP} / \mathrm{kg} \mathrm{DM}$ and then stayed relatively stationary, fluctuating between this latter value and $0 \cdot 72$ (Table 2 ).

The response in $\mathrm{AD}$ to changing dietary $\mathrm{N}$ concentrations was obviously asymptotic. The fitting of a curve $Y=a+(b / X)$, where $Y$ represents AD and $X$ dietary $\mathrm{N}$, with $a$ and $b$ constants, gave an equation $Y=0.758+(0.868 / X)$ and an $R^{2}$ of 0.899 . However with this 


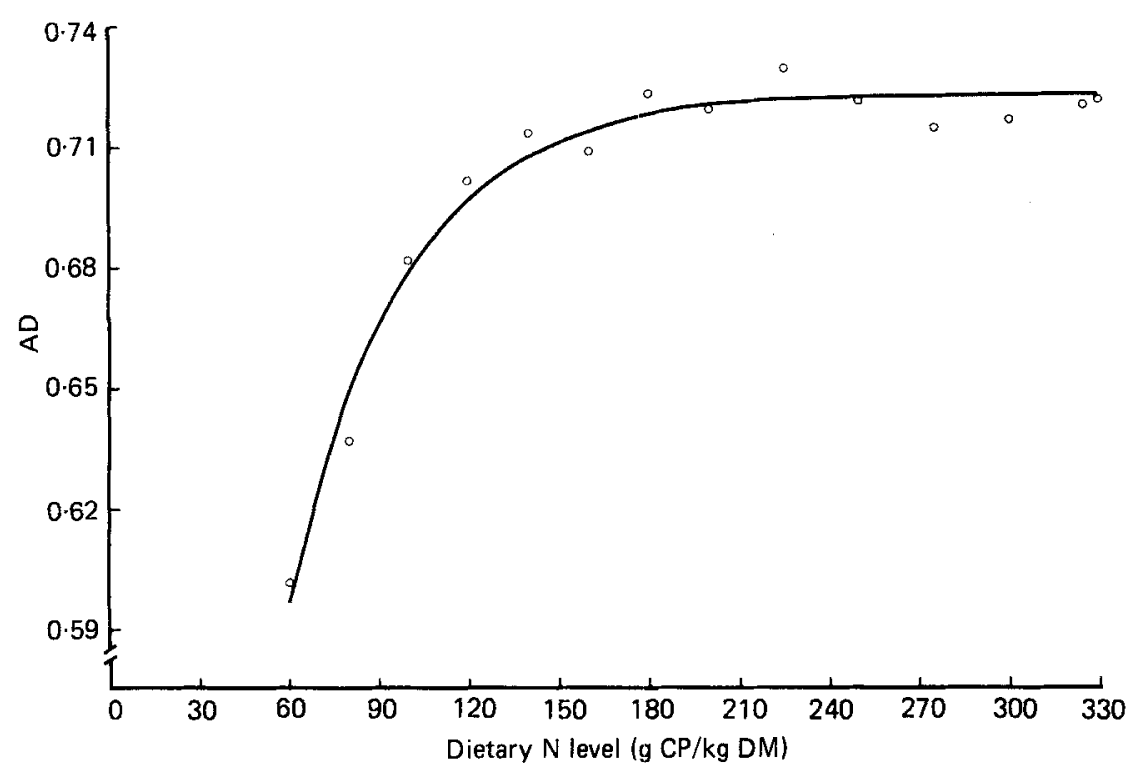

Fig. 1. Changes in apparent protein digestibility $(A D)$ with increasing dietary levels of nitrogen ( $\mathrm{g}$ crude protein $(\mathrm{N} \times 6.25 ; \mathrm{CP}) / \mathrm{kg}$ dry matter $(\mathrm{DM}))$. $(\mathrm{O})$, Observed treatment means. Fit has been tested with a modified Weibull equation $Y=a\left(1-\exp \left[-b X^{c}\right]\right)$ where $Y$ represents estimated AD and $X$ represents $C P$; $a$ is the asymptote, while $b$ and $c$ are scale and shape parameters respectively.

For line $Y=0.721\left(1-\exp \left[-0.3179 X^{0.9517}\right]\right), \mathrm{SE}_{Y} 0.010, R^{2} 0.922$.

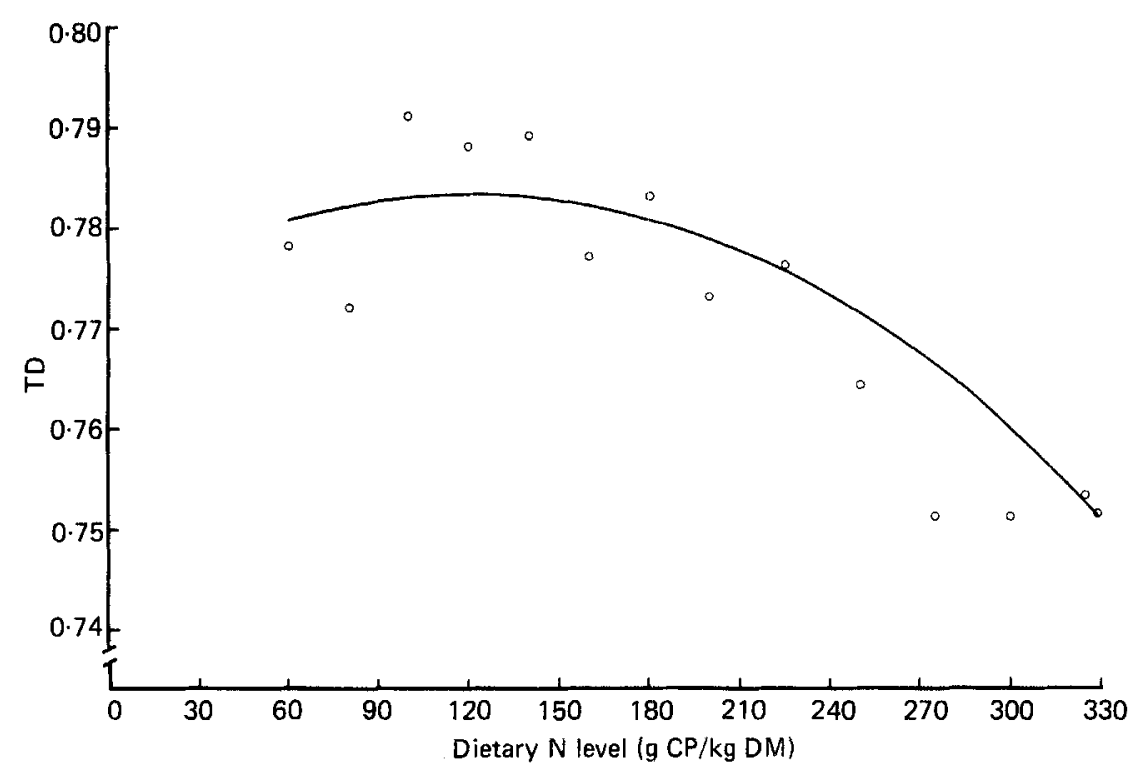

Fig. 2. Changes in true protein digestibility (TD) with increasing dietary levels of nitrogen (g crude protein $(\mathrm{N} \times 6.25 ; \mathrm{CP}) / \mathrm{kg}$ dry matter $(\mathrm{DM}))$. (O), Observed treatment means. Fit has been tested with the equation $Y=a+b_{1} X+b_{2} X^{2}$, where $Y$ represents estimated TD and $X$ represents CP.

For line $Y=0.773+0.00016 X-0.0000007 X^{2}, \mathrm{SE}_{Y} 0.0106, \mathrm{SE}_{a}=0.00013, \mathrm{SE}_{b_{1}} 0.00015$ $\mathrm{SE}_{b_{2}} 0 \cdot 00002, R^{2} 0 \cdot 59$. 


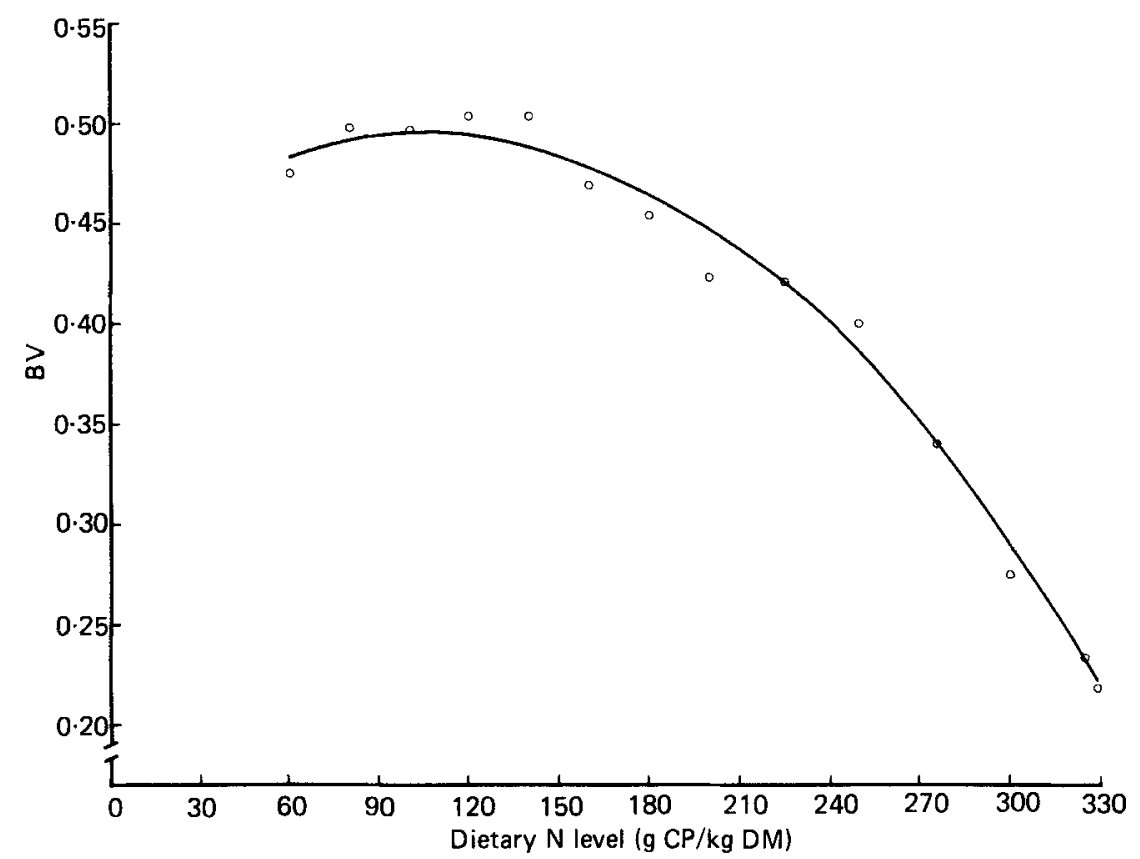

Fig. 3. Changes in biological value (BV) with increasing dietary levels of nitrogen ( $\mathrm{g}$ crude protein $(\mathrm{N} \times 6.25 ; \mathrm{CP}) / \mathrm{kg}$ dry matter $(\mathrm{DM}))$. (O), Observed treatment means. Fit has been tested with the equation $Y=a+b_{1} X+b_{2} X^{2}$ where $Y$ represents estimated $\mathrm{BV}$ and $X$ represents $\mathrm{CP}$.

For line $Y=0.436+0.00113 X-0.0000054 X^{2}, \mathrm{SE}_{Y} 0.0144, \mathrm{sE}_{a} 0.0017, \mathrm{SE}_{b_{1}} 0.00002, \mathrm{SE}_{b_{2}} 0.0000003, R^{2} 0.97$

fitting, the asymptote was considerably higher than the observed upper values. A better fit $\left(R^{2} 0.922\right)$ was given by the use of a modified Weibull equation. The derived equation (Fig. 1) was:

$$
Y=0.721\left(1-\exp \left[-0 \cdot 3179 X^{0 \cdot 9517}\right]\right)
$$

There was no significant variation in TD over the range of protein concentration from 60 to $225 \mathrm{~g} \mathrm{CP} / \mathrm{kg} \mathrm{DM}$, where it fluctuated between 0.772 and 0.791 (Table 2). It was only when the CP concentration rose to $250 \mathrm{~g} / \mathrm{kg}$ DM that there was a significant reduction, but even then it was small and showed no further reduction to the maximum $\mathrm{CP}$ level of $329 \mathrm{~g} / \mathrm{kg}$ DM.

The value for $R^{2}$ for neither the linear nor the quadratic equations of best fit was high $(0.51$ and 0.59 respectively) (Fig. 2). This could be explained by the narrow range of the TD values $(0.751-0.791)$ and the fact that the values tended to fluctuate in a rather poorly defined pattern over this range. However, the quadratic relation was significantly better than the linear relation.

\section{$B V$}

BV increased significantly from 0.475 at a CP level of $60 \mathrm{~g} / \mathrm{kg} \mathrm{DM}$ to 0.498 at $80 \mathrm{~g} / \mathrm{kg}$ $\mathrm{DM}$ and stayed at this level until CP rose to $160 \mathrm{~g} / \mathrm{kg} \mathrm{DM}$, when it started to decline at an increasing rate, to reach 0.216 at the maximum CP concentration of $329 \mathrm{~g} / \mathrm{kg} \mathrm{DM}$ (Table 2). 


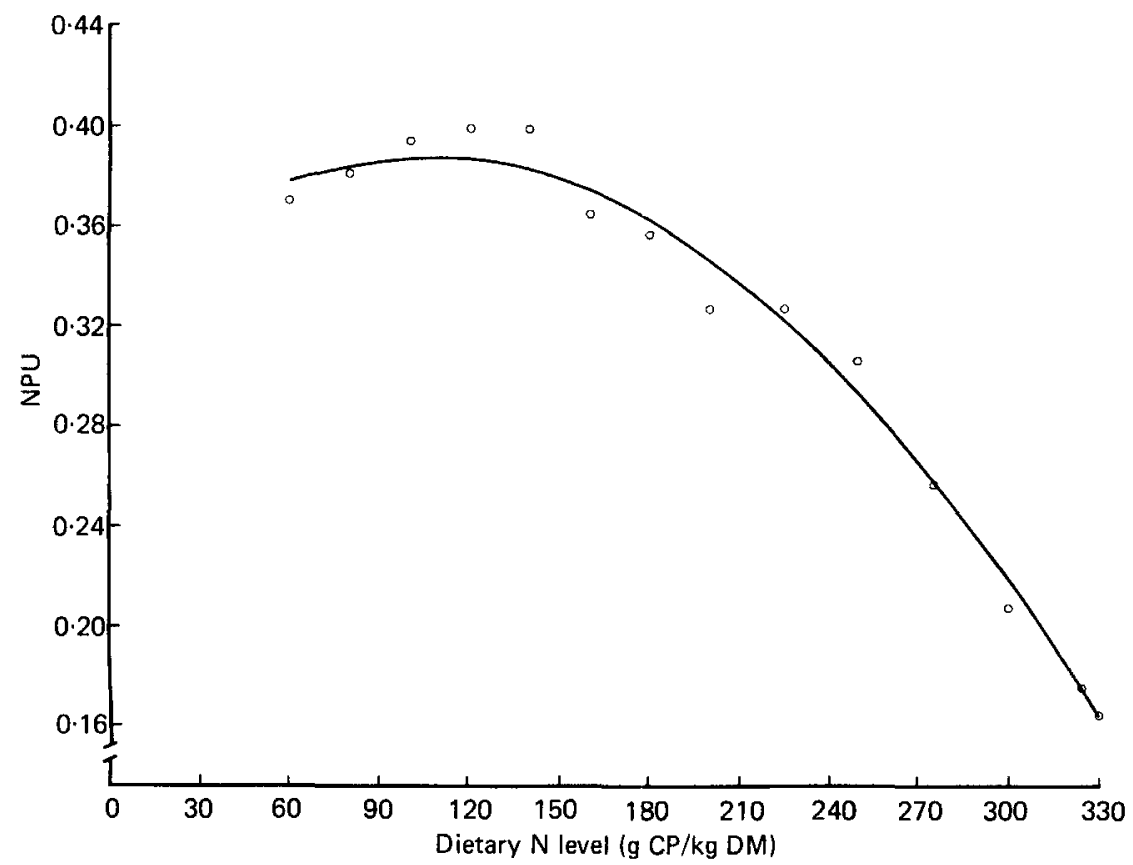

Fig. 4. Changes in net protein utilization (NPU) with increasing dietary levels of nitrogen ( $\mathrm{g}$ crude protein $(\mathrm{N} \times 6.25 ; \mathrm{CP}) / \mathrm{kg}$ dry matter $(\mathrm{DM}))$. (O), Observed treatment means. Fit has been tested with the equation $Y=a+b_{1} X+b_{2} X^{2}$ where $Y$ represents estimated NPU and $X$ represents $\mathrm{CP}$.

For line $Y=0.340+0.00091 X-0.0000044 X^{2}, \mathrm{SE}_{Y} 0 \cdot 0123, \mathrm{SE}_{a} 0.0015, \mathrm{SE}_{b_{1}}=0.000016, \mathrm{SE}_{b_{2}} 0.0000002, R^{2} 0.98$

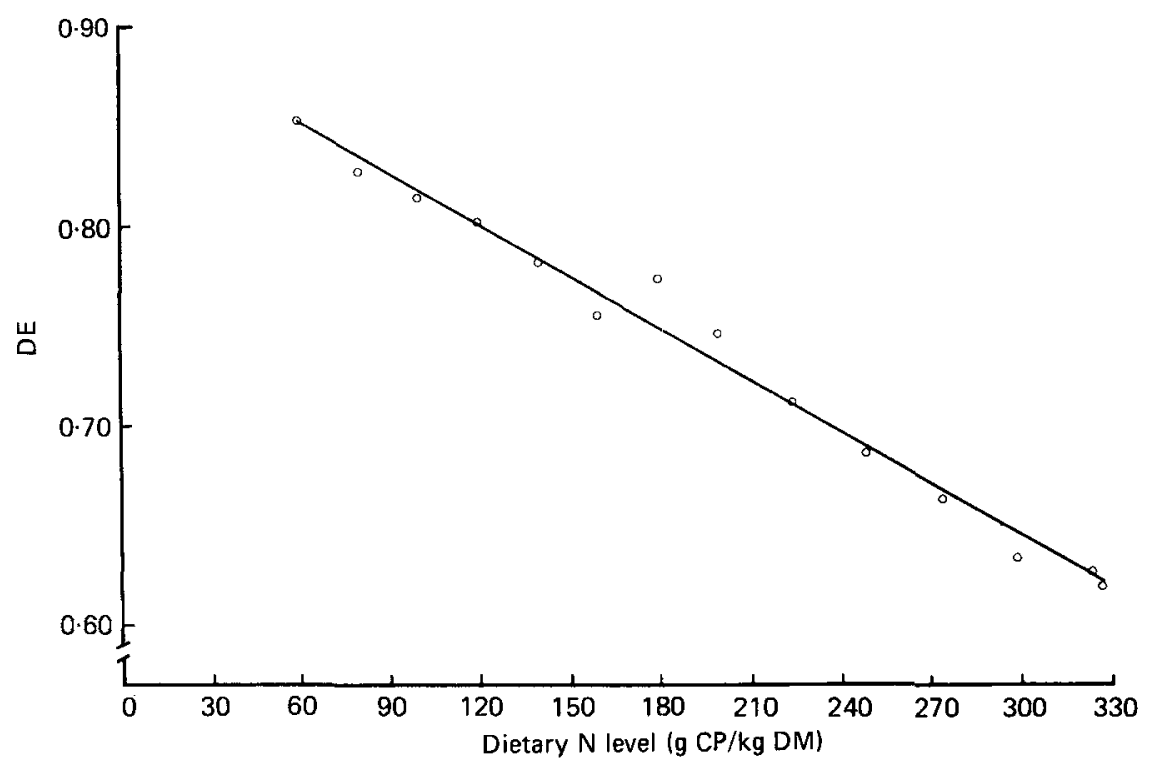

Fig. 5. Changes in apparent energy digestibility (DE) with increasing dietary level of nitrogen ( $\mathrm{g}$ crude protein $(\mathrm{N} \times 6.25) / \mathrm{kg}$ dry matter (DM)). (O), Observed treatment means. Fit has been tested with the equation $Y=a+b X$ where $Y$ represents estimated $D E$ and $X$ represents $C P$.

For line $Y=0.904-0.0086 X, \mathrm{sE}_{Y} 0.0012, \mathrm{SE}_{a} 0.0035, \mathrm{SE}_{b} 0.0002, R^{2} 0.97$. 
The values for BV closely fitted the quadratic equation

$$
Y=0.436+0.0113 X-0.00054 X^{2}\left(R^{2} 0.98\right)
$$

where $Y$ represents BV and $X$ represents CP concentration in g/kg DM (Fig. 3).

\section{$N P U$}

The response in NPU to an increasing dietary protein concentration closely paralleled the response in BV. NPU rose slightly but significantly from 0.370 for the CP level of $60 \mathrm{~g} / \mathrm{kg}$ DM to 0.384 for the CP level of $80 \mathrm{~g} / \mathrm{kg} \mathrm{DM}$, then plateaued until a level of $160 \mathrm{~g} \mathrm{CP} / \mathrm{kg}$ DM was reached. From this point, as CP concentration increased, the NPU values decreased at an increasing rate to reach a minimum value of 0.162 at the $\mathrm{CP}$ concentration of $329 \mathrm{~g} / \mathrm{kg}$ DM (Table 2).

The relation between NPU and CP closely fitted $\left(R^{2} 0.98\right)$ the quadratic equation

$$
Y=0 \cdot 0340+0 \cdot 0091 X-0.00044 X^{2}
$$

where $Y$ represents NPU and $X$ represents CP concentration (g/kg DM) (Fig. 4).

\section{$D E$}

DE decreased steadily from 0.851 at a CP level of $60 \mathrm{~g} / \mathrm{kg} \mathrm{DM}$ to 0.617 at the highest CP level of $329 \mathrm{~g} / \mathrm{kg}$ DM (Table 2 ). There was only a slight deviation of values from the straight line relation expressed by the equation $Y=0.904-0.0086 X\left(R^{2} 0.97\right)$ (Fig. 5).

\section{DISCUSSION}

A combination of wheat bran and meat-and-bone meal should have the potential to stimulate bacterial growth in the digestive tract and thus, when incorporated at varying levels, to influence the indices $\mathrm{AD}, \mathrm{TD}, \mathrm{BV}$ and $\mathrm{DE}$ which are frequently applied as criteria in the measurement of the nutritive value of foods.

In agreement with earlier work of Eggum (1973) and Eggum et al. (1985), AD was strongly affected by the dietary protein level. The best fit was obtained with an asymptotic function. This relation has been discussed by Eggum (1973), who considered it to be due to an assumed constancy of metabolic $\mathrm{N}$ excretion, with this excretion constituting a greater proportion of the total faecal $\mathrm{N}$ at the lower protein levels. As emphasized by Njaa (1963), a sharp distinction must be made between the concepts of TD and $\mathrm{AD}$. The latter concept is meaningful only under strictly standardized conditions. Eggum (1973) also stated that TD can be regarded as a characteristic of the particular protein source regardless of the dietary conditions under which it is given. However, in later work, Eggum et al. (1985) concluded that TD is not always independent of dietary protein concentration. An elevation of the dietary protein level from $15 \mathrm{~g} \mathrm{~N} / \mathrm{kg} \mathrm{DM}$ to $30 \mathrm{~g} \mathrm{~N} / \mathrm{kg}$ DM decreased the mean TD value of nine protein sources from 0.887 to 0.876 . However, this reduction was small and was significant only for skim-milk powder, barley and brown beans, with the reduction for brown beans, from 0.680 to 0.638 , being markedly greater than that for any of the other protein sources. This was interpreted as being due to the high amounts of easily-fermentable soluble fibre in brown beans. In the present study there was no significant variation in TD over the range of protein concentrations from 60 to $225 \mathrm{~g} \mathrm{CP} / \mathrm{kg}$ $\mathrm{DM}$, where it fluctuated between 0.772 and 0.791 . It was only when the CP concentration rose to $250 \mathrm{~g} / \mathrm{kg} \mathrm{DM}$ that there was a significant reduction, but even then it was small and showed no further reduction at the maximum CP level of $329 \mathrm{~g} / \mathrm{kg}$ DM. However, in contrast to the results of Eggum (1973), the TD values of 0.772 to 0.791 obtained with $60-225 \mathrm{~g} \mathrm{CP} / \mathrm{kg}$ DM were significantly different from the asymptotic value of 0.758 
estimated from the regression of $\mathrm{AD}$ on $\mathrm{CP}$. On the other hand, the asymptotic value corresponds much better to the TD values of $0.751-0.764$ which were obtained with protein concentrations from 250 to $329 \mathrm{~g} / \mathrm{kg}$ DM. Based on these results and on earlier findings (Eggum, 1973; Eggum et al. 1985) it is concluded that TD generally is independent of dietary protein concentration, although exceptions might occur. It is further assumed that these exceptions occur because of microbial fermentation in the hind-gut.

In a review, Corring (1980) quoted results indicating an adaptation of digestive enzymes to the amount of nitrogenous material ingested, although the quantity of this endogenous $\mathrm{N}$ could not be determined from this review. The major factors which would modify the level of $\mathrm{N}$ in the faeces which was not a component of undigested food residues would appear to be trypsin inhibitors (Liener, 1979) and the presence in the hind-gut of easily-fermentable material, such as starch from uncooked potatoes (Beames \& Eggum, 1981) and fibre. Fibre in the hind-gut has a lower effect than starch in changing the route of $\mathrm{N}$ excretion, although if the fibre is highly fermentable the effect would be increased, as suggested by Eggum et al. (1985) for brown beans. In the absence of these modifying factors, it would be expected that if, as proposed by Eggum (1973), TD is a characteristic of each protein, TD should remain constant over a range of protein levels, but only if the value for metabolic faecal $N(M F N)$ is correctly chosen. There has been considerable debate over the correct value for MFN (Eyre, 1984, 1985). Eyre (1985) contrasted his calculated value of MFN of $0.90-1.30 \mathrm{mg} / \mathrm{g}$ DM intake with the 2.04 of Eggum (1973). This considerable difference is difficult to explain because, if MFN is related to metabolic body-weight (as suggested by Lloyd et al. (1978)), one would expect a higher value for the rats of Eyre (1985) which weighed more but were receiving slightly less feed. If the value used by Eggum (1973) for MFN is correct and his contention that TD is a characteristic of a particular protein source is also correct, TD should remain constant until the dietary $\mathrm{N}$ intake results in an elevated concentration of blood urea, some of which may migrate into the gastrointestinal tract (Rerat et al. 1979). The present results indeed do suggest that both the value and the contention are correct.

BV increased slightly but significantly from 0.475 at a CP level of $60 \mathrm{~g} / \mathrm{kg} \mathrm{DM}$ to 0.498 at $80 \mathrm{~g} / \mathrm{kg} \mathrm{DM}$ and stayed at this level until CP rose to $160 \mathrm{~g} / \mathrm{kg} \mathrm{DM}$, when it started to decline at an increasing rate to reach 0.216 at the maximum CP concentration of $329 \mathrm{~g} / \mathrm{kg}$ $\mathrm{DM}$. The values for $\mathrm{BV}$ closely fitted a quadratic equation, which is in agreement with earlier work of Eggum (1973) when casein supplemented with $10 \mathrm{~g}$ DL-methionine $/ \mathrm{kg}$ and soya-bean meal were the protein sources. However, the relation between $\mathrm{CP}$ and BV differed for all three protein sources, thus demonstrating that there is no fixed relation between CP and BV for various protein sources. This could also be concluded from the work of Eggum et al. (1985).

DE decreased steadily from 0.851 at a CP level of $60 \mathrm{~g} / \mathrm{kg} \mathrm{DM}$ to 0.617 at the highest $\mathrm{CP}$ level of $329 \mathrm{~g} / \mathrm{kg} \mathrm{DM}$. The reductions in DE were surely due to the increasing levels of dietary fibre in these diets. The wheat bran and meat-and-bone meal mixture $(1: 1, \mathrm{w} / \mathrm{w}$, DM basis) contained $199 \cdot 1 \mathrm{~g}$ total dietary fibre $/ \mathrm{kg}$ of which $185 \cdot 1 \mathrm{~g}$ was insoluble dietary fibre, which has very low digestibility (fermentability) in simple-stomached animals. These results are in agreement with those of Donangelo \& Eggum (1985), showing a strict negative relation between DE and total dietary fibre from wheat bran.

To summarize, the relation between AD and dietary protein level is best described by an asymptotic function which illustrates why $A D$ values should be compared only at a fixed protein concentration. However, TD is, with few exceptions, independent of the dietary protein over a wide range of concentrations. BV and NPU closely fit a quadratic function but these functions differ between the various protein sources. DE is strongly negatively related to total dietary fibre. 


\section{REFERENCES}

Asp, N.-G., Johansson, C.-G., Hallmer, H. \& Siljeström, M. (1983). Journal of Agricultural and Food Chemistry 31, 476-482.

Association of Official Analytical Chemists (1975). Official Methods of Analysis, 11th ed. Washington, DC: Association of Official Analytical Chemists.

Bach Knudsen, K. E. \& Eggum, B. O. (1984). Zeitschrift für Tierphysiologie, Tierernährung und Futtermittelkunde 51, 130-147.

Bach Knudsen, K. E., Wolstrup, J. \& Eggum, B. O. (1984). Zeitschrift für Tierernährung und Futtermittelkunde 52, 182-193.

Beames, R. M. \& Eggum, B. O. (1981). British Journal of Nutrition 46, 301-313.

Bjerring, J. H., Greig, M. \& Halm, J. (1975). U.B.C. BMD 10V. Vancouver, British Columbia: Computing Centre of the University of British Columbia.

Corring, T. (1980). Reproduction, Nutrition et Développement 20, 1217-1235.

Donangelo, C. M. \& Eggum, B. O. (1985). British Journal of Nutrition 54, 741-751.

Eggum, B. O. (1973). National Institute of Animal Science, Copenhagen, Report no. 406, p. 173.

Eggum, B. O., Beames, R. M. \& Bach Knudsen, K. E. (1985). British Journal of Nutrition 54, 727-739.

Eggum, B. O. \& Christensen, K. D. (1975). In Breeding for Seed Protein Improvement Using Nuclear Techniques, pp. 135-143. Vienna: International Atomic Energy Agency.

Eyre, M. D. (1984). Journal of the Science of Food and Agriculture 35, 647-656.

Eyre, M. D. (1985). Journal of the Science of Food and Agriculture 36, 11-25.

Fleming, S. E. \& Vose, J. R. (1979). Journal of Nutrition 109, 2067-2075.

Le, C. \& Tenisci, T. (1978). U.B.C. TRP. Vancouver, British Columbia: Computing Centre of the University of British Columbia.

Liener, I. E. (1979). In Biochemistry of Nutrition, vol. 27, pp. 97-122. [A. Newberger and T. H. Jukes, editors]. Baltimore: University Park Press.

Lloyd, L. E., McDonald, B. E. \& Crampton, E. W. (1978). Fundamentals of Nutrition, 2nd ed. San Francisco: W. H. Freeman and Co.

MacRae, J. C. \& Armstrong, D. G. (1968). Journal of the Science of Food and Agriculture 19, 578-582.

Mason, V. C. (1978). Proceedings of 3rd World Congress on Animal Feeding, Madrid, pp. 197-210. International Veterinary Association for Animal Production.

Mason, V. C., Bech-Andersen, S. \& Rudemo, M. (1980). Zeitschrift für Tierphysiologie, Tierernährung und Futtermittelkunde 43, 146-164.

Mason, V. C. \& Just, A. (1976). Zeitschrift für Tierphysiologie, Tierernährung und Futtermittelkunde 36, $301-310$.

Njaa, L. R. (1963). Reports on Technological Research Concerning Norwegian Fish Industry, vol. 4, no. 5. Bergen, Griegs Boktrykkeri.

Rerat, A. (1978). Journal of Animal Science 46, 1808-1837.

Rerat, A., Lisoprawski, C., Vaissade, P. \& Vaugelade, P. (1979). Bulletin de l'Académie Veterinaire de France 52, 333-341.

Stoldt, W. (1957). Fette, Seifen, Anstrichmittel 54, 206-207.

Yang, R. C., Kozak, A. \& Smith, J. H. G. (1978), Canadian Journal of Forest Research 8, 424-431. 